\title{
Mainstreaming Sustainable Development Goals (SDGs) into Local Development Planning: Lessons from Adentan Municipal Assembly in Ghana
}

\author{
Ellen Forkuo Duah ${ }^{1}$, Albert Ahenkan $^{1} \&$ Daniel Larbi ${ }^{2}$ \\ ${ }^{1}$ University of Ghana Business School, Ghana \\ ${ }^{2}$ Accra Technical University, Ghana \\ Correspondence: Albert Ahenkan, University of Ghana Business School, Ghana. E-mail: aahenkan@ug.edu.gh
}

Received: May 30, 2020

doi:10.5539/jsd.v13n5p79
Accepted: September 3, $2020 \quad$ Online Published: September 29, 2020

URL: https://doi.org/10.5539/jsd.v13n5p79

\begin{abstract}
The Sustainable Development Goals (SDGs), which were adopted in September 2015 represent a challenging worldwide action plan that aims to end poverty, achieve gender equality, in diverse dimensions, promote decent work among others. Global realization of the SDGs by 2030 is highly dependent on the localization and effective implementation of the goals, yet little is known about diverse perspective of SDG localization and challenges involved. It is in response to this that the study examines the magnitude to which SDGs have been integrated into local development planning using Adentan municipal as a case study. A qualitative method with an in-depth interview of 20 key informants was adopted. The study developed a conceptual framework which was used to examine Adentan municipal Assembly on SDG mainstreaming. The study also did a critical analysis of the medium-term development plan of the municipal assembly to identify how the Assembly has effectively mainstreamed the SDGs at the local level. The findings from the study revealed that the authorities are aware of the SDGs. Majority of the targets in SDGs $(1,2,3,4,5,6,8,9,10,11,13,14,16$ and 17) have been integrated into the local development plan of the Assembly. However, SDG 7 and 15 were of no interest to the municipal. The findings further indicated that financing, low awareness of the relevance of the SDGs among the citizens in the municipality and bureaucracy are the major challenges of SDG mainstreaming at the local level. The study proposed a framework which extends the theory of change on effective SDG mainstreaming and can be added to other existing framework on SDG mainstreaming at the local level to address the challenges and needs of SDG mainstreaming for development initiative and may inform future research in mainstreaming and planning.
\end{abstract}

Keywords: local development planning, mainstreaming, sustainable development, sustainable development goals, SDG challenges, local economic development

\section{Introduction}

Sustainable development has moved to the centre of global development agenda. The seventeen sustainable development goals were adopted in September 2015 (Muff et al, 2017) to combat urgent social, economic and environmental problems in the world. Ghana adopted the SDGs which came into effect in January 2016 to build upon the accomplishments of the Millennium Development Goals (MDGs). Globally, the SDGs are being mainstreamed by countries into national and local development plans. Lepuschitz (2015) identified national efforts for integrating SDGs in developed countries such as Belgium, Germany, Latvia, and Slovenia among others. The aim is to institutionalize the SDGs into national development processes. Despite the integration of SDGs at national level globally, the implementation of the SDGs cannot be fully felt unless local people at the grassroots are involved hence this calls for more studies on SDGs to be done at the local level.

Ghana's adoption of the SDGs requires the Government to put in place strategies to mainstream them into sectoral and local development plans to ensure efficient and effective implementation. The starting point for localization and effective implementation is to integrate the SDGs into the medium-term development plans of the Metropolitan, Municipal and District Assemblies (MMDAs). The Medium-term Development Plans (MTDPs) are meant to assist MMDAs in translating the national policies and strategies for implementation. The MTDP of the MMDAs is an important vehicle for the realization of SDGs at the local level by putting in place plans and strategies to make goals a normal thing in the development planning, budgeting, implementation, monitoring and evaluation 
processes (PAGE, 2017). The study therefore seeks to assess the level to which the SDGs have been mainstreamed into medium-term development plans of the MMDAs using Adentan Municipal Assembly in Ghana as Case Study. The study adds to literature on SDG mainstreaming challenges faced at the local level in developing countries.

\section{Mainstreaming of SDGs}

The term mainstreaming has been used extensively in development; it has been used since the 1990s to track development matters especially in developing countries (Oates Conway \& Calow, 2011; Lebel et al., 2012). Ribeiro (2018) defined mainstreaming as "the integration of policies and measures into spatial planning and decision making processes". Uittenbroek et al. (2012) gave more detailed definition of mainstreaming, according to authors, mainstreaming is about promoting efficient, effective and more sustainable use of resources than managing and designing policies separately from on-going activities. The study relates more with this definition because mainstreaming goes beyond integrating the SDGs into local development planning, it goes beyond managing and designing policies to further center on looking at the effectiveness of the plan goals; how effective are the planning stages of mainstreaming the goals, effective reporting systems, monitoring and evaluation, implementation to ensure that the mainstreamed goals have been achieved and many others.

According to Hug and Ayers (2008) mainstreaming may take 5 to 7 years and they came up with four steps in mainstreaming. The first step centers on 'awareness raising and building scientific capacity, the second step is on targeted information, third; pilot activities and fourth; mainstreaming. Awareness raising and building scientific capacity involves sensitization thus building the awareness of the need for the mainstreaming, profiling and mapping, assessing the people vulnerability among others. Targeted information, the second step is about gaining, acquiring information for policy makers and key stakeholders to enhance their capability skills and knowledge for mainstreaming. The third step is about the implementation of pilot activities where the implementation of the policy actually takes place and the last step looks at the mainstreaming processes where the lesson from implementation process are reviewed, how it can fed-back into policy and planning among others (Atanga et. al, 2017) however, aside these factors other technical and more challenging factors can also be used to mainstream the goals hence the need for more research in this area.

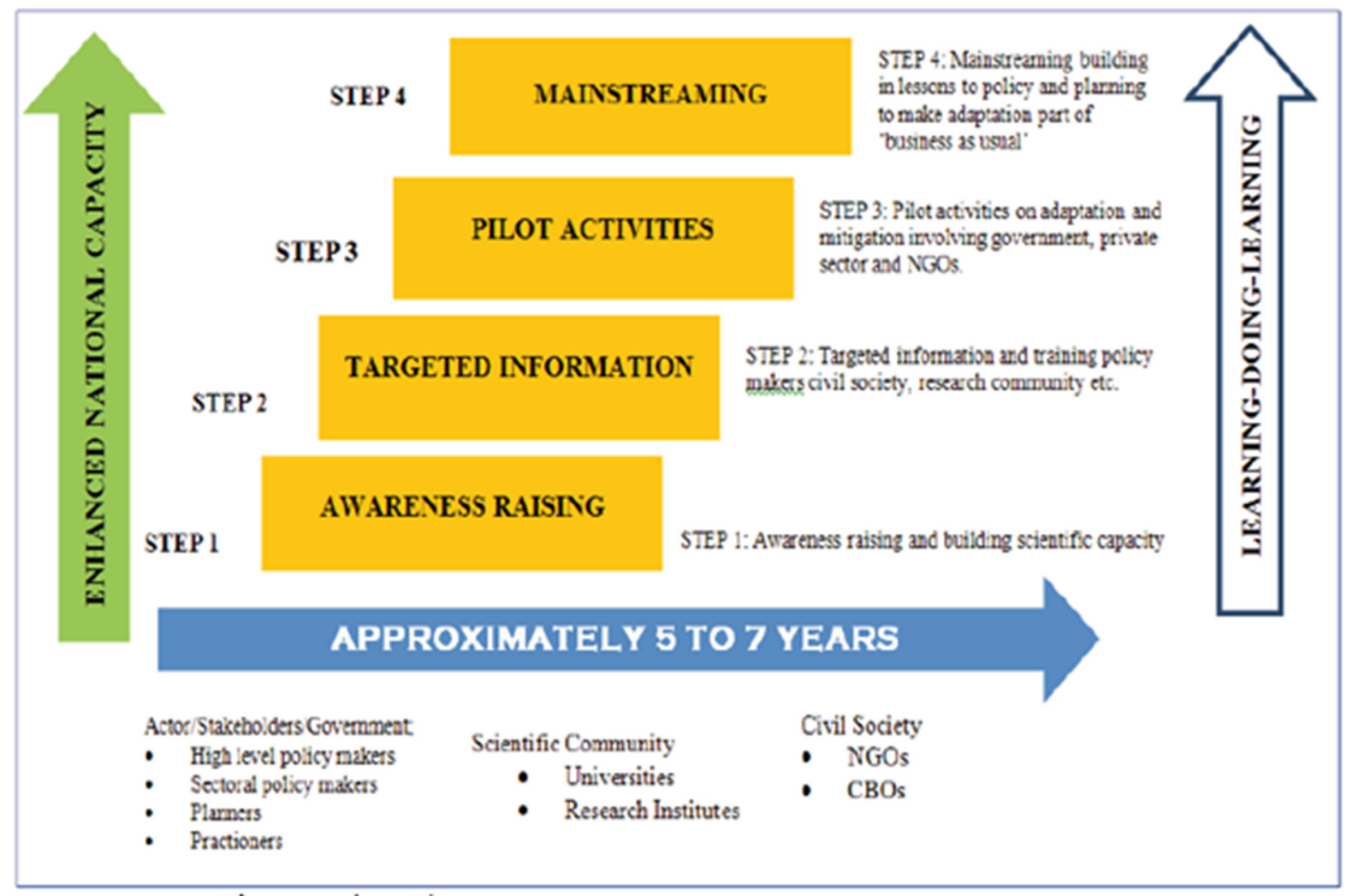

Figure 1. Four-Step Framework for mainstreaming adaptation

Source: Huq and Ayers (2008) 
According to Alhassan \& Hadwen (2017), measures which prevent the integration of climate change include inadequate information about the vulnerability of the municipal to climate change and its hazards and no institutional structures to mainstream into Assembly plans. For him, the following recommendation was suggested to mainstream climate change adaptation into development planning for the municipality: capacity building, institutionalizing and coordination of climate change, legislative support, instituting early cautionary systems and disasters risk readiness and integrating democratic approach to development planning. Hug and Ayers under capacity building indicated that mainstreaming should commence with building awareness and capabilities and recommended that local government organize sensitization programs and training workshops so that stakeholders will be educated on how to integrate climate change effectively. On institutionalizing and coordination of climate change, the author said that there are no structures to integrate climate change and suggested the Ministry of Local Government and Rural Development create offices for climate change at the district level. The issue gap identified was that aside climate change it is essential to also research on other goals of the SDGs.

According to Okafor-Yawood (2019), SDG 1 and 2, which are about ending hunger, ensuring sustainable agriculture, food security and improved health, can only be attained if SDG 14 is achieved. For instance, fish serves as a source of financial gain for lots of people in the communities (Ntona\& Morgera, 2018) which allows them the chance to educate their children in school. The decline in fisheries will affect the achievement of SDG 4 - quality education for all. Also, fisheries which is a source of protein for millions of people would mean that illegal, unreported and unregulated fishing (IUU fishing) threatens the acquisition of SDG 3 - ensuring healthy lives. More so, the economic damage of IUU fishing perhaps can threaten the ability to attain SDG8 and as such, the author holds that achieving the preservation of the ocean, seas and marine resources (SDG 14) is crucial to realizing other SDGs, especially SDG 1, SDG 2, SDG 3, SDG 4 and SDG 8. It is equally relevant to also stress that all the SDGs impacts the other for instance eradicating poverty have an impact on ending hunger, quality education, health among others hence the need to research about them.

Lucci \& Lally (2016) advised that secured political leadership which is a major factor in achieving the goals, institutions which Alhassan \& Hadwen (2017) also emphasized and financing are important mechanism towards achieving SDGs. More so, high commitments from political officials are important for implementing SDG. Weymounth \& Hartz-Karp (2018) also indicated the need for partnership between governments, private and public sectors, citizens and nations for effective SDG mainstreaming. Moreso, the authors emphasized that reform governance was necessary for the integration and they apply the governance principle to a model. The model involved first starting an inclusive and democratic process of localizing, set the local SDG agenda; plan for SDG implementation and supervise SDG progress".

\section{Methodology}

The study uses purely qualitative research methods. The study seeks to examine how the SDGs are mainstreamed into local development planning. Qualitative approach was adopted for the study with an in-depth interview guide and open-ended questionnaire for data collection. A total of twenty (20) respondents were sampled for the study. The target population included one (1) Metropolitan, Municipal and District Chief Executives (MMDCEs), three Planning Officers, two District Coordinating Directors, three Finance Officers, three budget officers of Metropolitan and eight (8) Assemblymen. The participants were selected using purposive sampling techniques. The technique was used because specific participants involvement in the mainstreaming and their specific knowledge in the SGDs. These are people responsible for decision making, planning, budgeting, mainstreaming, and implementation of SDGs in the Municipality. The data collected was transcribed and analyzed through thematic analysis. The development of themes and the analysis were based on the objectives of the study. The themes reflected the overall aim of the study. The emerging themes were organized and discussed according to the objectives of the study.

\section{Findings and Discussion}

This section presents the findings and discussions on how the Sustainable Development Goals (SDGs) are mainstreamed at the local level at the Adentan Municipal Assembly.

\subsection{Mainstreaming of SDGs at the Local Level}

The medium-term development plan of the assembly was reviewed and compared with the global goals and also with the National Development Planning Commission (NDPC) framework. The NDPC framework was given to all Metropolitan, Municipal and District Assemblies in Ghana as a guide in mainstreaming the SDGs. This was evident when a responded said:

\footnotetext{
"we get the guidelines from the NDPC and when we are doing our plans, we incorporate them into the plan"
} 
Table 1. Summary of the mainstreamed SDGs and targets of the municipal

\begin{tabular}{|c|c|c|}
\hline SDGs and Targets & & Adentan Municipal \\
\hline \multirow[t]{2}{*}{ Goal 1: End Poverty } & $\begin{array}{l}\text { Mainstreamed } \\
\text { Targets }\end{array}$ & $\begin{array}{l}\text { Eradicate extreme poverty. Implement social protection system. Ensure } \\
\text { equal right to economic resources from variety sources. }\end{array}$ \\
\hline & $\begin{array}{l}\text { Targets not } \\
\text { mainstreamed }\end{array}$ & $\begin{array}{l}\text { Create pro-poor and gender-sensitive development strategies to support } \\
\text { poverty reduction. Reduce by half the proportion of people who are poor by } \\
\text { national definition. }\end{array}$ \\
\hline \multirow[t]{2}{*}{ Goal 2: End hunger } & $\begin{array}{l}\text { Mainstreamed } \\
\text { Targets }\end{array}$ & $\begin{array}{l}\text { End hunger and ensure access by all. Ensure sustainable food production } \\
\text { systems. Double agricultural productivity and incomes of small scale food } \\
\text { producers. }\end{array}$ \\
\hline & $\begin{array}{l}\text { Targets not } \\
\text { mainstreamed }\end{array}$ & $\begin{array}{l}\text { Adopt measures to ensure the proper functioning of food commodity market. } \\
\text { Prevent trade restrictions. }\end{array}$ \\
\hline \multirow[t]{2}{*}{$\begin{array}{l}\text { Goal 3: Ensure healthy } \\
\text { lives }\end{array}$} & $\begin{array}{l}\text { Mainstreamed } \\
\text { targets }\end{array}$ & $\begin{array}{l}\text { Reduce by one third premature mortality from non-communicable diseases. } \\
\text { Ensure access to sexual and reproductive health- care services. Achieve } \\
\text { universal health coverage. Reduce deaths from hazardous chemicals air, } \\
\text { water and soil pollution. Reduce maternal mortality ratio to less than } 70 \text { per } \\
100,000 \text { live births. End epidermis of AIDS, tuberculosis, malaria and } \\
\text { tropical diseases. }\end{array}$ \\
\hline & $\begin{array}{l}\text { Targets not } \\
\text { mainstreamed }\end{array}$ & $\begin{array}{l}\text { End preventable death of new born and children under } 5 \text { years. Strengthen } \\
\text { the prevention and treatment of substance abuse. Halve the number of global } \\
\text { deaths. Implementation of the World Health Organization Framework } \\
\text { Convention on Tobacco control. }\end{array}$ \\
\hline \multirow[t]{2}{*}{$\begin{array}{l}\text { Goal } 4: \\
\text { Education }\end{array}$} & $\begin{array}{l}\text { Mainstreamed } \\
\text { Targets }\end{array}$ & $\begin{array}{l}\text { Ensure all girls and boys complete free, equitable and quality education. } \\
\text { Increase the number of youths and adults with relevant skills. Ensure that all } \\
\text { youth achieve literacy and numeracy. Ensure all learners acquire the } \\
\text { knowledge and skills needed to promote sustainable development. Build and } \\
\text { upgrade educational facilities. increase the supply of quality teachers }\end{array}$ \\
\hline & $\begin{array}{l}\text { Targets not } \\
\text { mainstreamed }\end{array}$ & $\begin{array}{l}\text { Expand the number of scholarships available for enrollment in higher } \\
\text { education. Equal access to affordable and quality technical, vocational and } \\
\text { tertiary education }\end{array}$ \\
\hline \multirow{3}{*}{$\begin{array}{l}\text { Goal 5: Achieve Gender } \\
\text { Equality }\end{array}$} & Mainstreamed & Eliminate all harmful practices such as early and forced marriage and FGM. \\
\hline & Targets & $\begin{array}{l}\text { Adopt and strengthen policies to empower women. End discrimination } \\
\text { against women. Eliminate all forms of violence against women. Recognize } \\
\text { and value unpaid care and domestic work. }\end{array}$ \\
\hline & $\begin{array}{l}\text { Targets not } \\
\text { mainstreamed }\end{array}$ & $\begin{array}{l}\text { Empower women in technology. Undertake reforms to give women equal } \\
\text { right to economic resources. Ensure access to sexual and reproductive right. } \\
\text { Ensure women's full participation and equal opportunities for leadership at } \\
\text { all levels of decision making }\end{array}$ \\
\hline $\begin{array}{l}\text { Goal 6: Sustainable } \\
\text { management of water } \\
\text { and sanitation }\end{array}$ & $\begin{array}{l}\text { Mainstreamed } \\
\text { Targets }\end{array}$ & $\begin{array}{l}\text { Expand international corporation to support water and sanitation activities } \\
\text { and programmes. Improve water quality by reducing pollution. Achieve } \\
\text { access to adequate and equitable sanitation and hygiene and end open } \\
\text { defecation }\end{array}$ \\
\hline
\end{tabular}


Target not Achieve equitable access to save and affordable drinking water. Increase mainstreamed water use efficiency. Implement water resources management at all levels. Support the participation improving water and sanitation management.

\section{Goal 7: Sustainable and}

Energy for all
Only one target were captured in the plan which was on improving energy efficiency.

\begin{tabular}{|c|c|c|}
\hline $\begin{array}{l}\text { Group 8: Decent work } \\
\text { and economic growth }\end{array}$ & $\begin{array}{l}\text { Mainstreamed } \\
\text { Target }\end{array}$ & $\begin{array}{l}\text { Take measures to eradicate forced labour. End modern slavery and human } \\
\text { trafficking. } \\
\text { Promote policies that support decent job creation. Achieve productive } \\
\text { employment and decent work for all. Reduce the proportion of youth not } \\
\text { employed. }\end{array}$ \\
\hline & $\begin{array}{l}\text { Targets not } \\
\text { Mainstreamed }\end{array}$ & $\begin{array}{l}\text { Strengthen the capacity of domestic financial institutions. Develop and } \\
\text { operationalize a global strategy or youth employment. Sustain per capita } \\
\text { economic growth in accordance with national circumstances. Achieve higher } \\
\text { levels of economic productivity. Improve resources efficiency in } \\
\text { consumption and production. Increase Aid for Trade support for developing } \\
\text { countries. }\end{array}$ \\
\hline
\end{tabular}

\begin{tabular}{|c|c|c|}
\hline \multirow[t]{2}{*}{$\begin{array}{l}\text { Goal 9: Build } \\
\text { infrastructure and foster } \\
\text { innovation }\end{array}$} & $\begin{array}{l}\text { Mainstreamed } \\
\text { Targets }\end{array}$ & $\begin{array}{l}\text { Develop quality, sustainable infrastructure. Promote sustainable } \\
\text { industrialization. Increase the access of small-scale industrial and other } \\
\text { enterprises. Upgrade infrastructure and industries to make them sustainable. } \\
\text { Support domestic technology develop research and innovation. }\end{array}$ \\
\hline & $\begin{array}{l}\text { Targets not } \\
\text { mainstreamed }\end{array}$ & $\begin{array}{l}\text { Enhance scientific research upgrade technological capabilities of industrial } \\
\text { sectors. }\end{array}$ \\
\hline \multirow[t]{2}{*}{$\begin{array}{l}\text { Goal } 10 \text { : } \\
\text { Inequality }\end{array}$} & $\begin{array}{l}\text { Mainstreamed } \\
\text { Target }\end{array}$ & $\begin{array}{l}\text { Empower and promote social, economic and political inclusion for all } \\
\text { irrespective of age, sex, disability, race etc. ensure equal opportunity and } \\
\text { reduce inequalities of outcome. }\end{array}$ \\
\hline & $\begin{array}{l}\text { Target not } \\
\text { mainstreamed }\end{array}$ & $\begin{array}{l}\text { Adopt policies in achieving equality. Improve regulation and monitoring of } \\
\text { financial markets and institutions. Facilitate orderly, safe and responsible } \\
\text { migration and mobility of people etc. }\end{array}$ \\
\hline \multirow[t]{2}{*}{$\begin{array}{l}\text { Goal 11: Make human } \\
\text { settlement safe and } \\
\text { sustainable }\end{array}$} & $\begin{array}{l}\text { Mainstreamed } \\
\text { Target }\end{array}$ & $\begin{array}{l}\text { Ensure access for all to safe and affordable housing and upgrade slums. } \\
\text { Provide access to safe, affordable and sustainable transport systems. Support } \\
\text { economic, social and environmental links between urban and rural areas by } \\
\text { strengthening national and regional development planning. }\end{array}$ \\
\hline & $\begin{array}{l}\text { Targets not } \\
\text { mainstreamed }\end{array}$ & $\begin{array}{l}\text { Enhance sustainable urbanization. Strengthen efforts to protect cultural and } \\
\text { natural heritage. Reduce the number of deaths caused by disasters including } \\
\text { water-related disasters. }\end{array}$ \\
\hline \multirow[t]{2}{*}{$\begin{array}{l}\text { Goal 12: Sustainable } \\
\text { Consumption and } \\
\text { Production Patterns }\end{array}$} & $\begin{array}{l}\text { Mainstreamed } \\
\text { Target }\end{array}$ & $\begin{array}{l}\text { Achieve sound management of chemicals and wastes. Promote public } \\
\text { procurement practices that are sustainable. Ensure that people have } \\
\text { information and awareness for sustainable development. Reducing waste } \\
\text { generation through prevention, reduction, recycling and reuse. }\end{array}$ \\
\hline & $\begin{array}{l}\text { Target not } \\
\text { mainstreamed }\end{array}$ & $\begin{array}{l}\text { Implement } 10 \text { Year- Framework of Program on sustainable consumption and } \\
\text { production patterns. Achieve sustainable management and efficient use of } \\
\text { national resources. Halve per capita global food waste. Encourage companies }\end{array}$ \\
\hline
\end{tabular}


to adopt sustainable practices and to integrate sustainability information into their reporting recycle etc.

Goal 13: Combat climate Mainstreamed Integrate climate change measures into policies and planning. Improve change and its impacts target education on climate change mitigation. Promote mechanism for raising capacity for effective climate change related planning etc

\begin{tabular}{|c|c|c|}
\hline & & \\
\hline & $\begin{array}{l}\text { Targets not } \\
\text { mainstreamed }\end{array}$ & $\begin{array}{l}\text { Promote mechanisms for raising capacity for effective climate change- } \\
\text { related planning and management. Strengthen resilience and adaptive } \\
\text { capacity to climate-related hazards. }\end{array}$ \\
\hline \multirow{6}{*}{$\begin{array}{l}\text { Goal 14: Conserve } \\
\text { Oceans, seas and } \\
\text { hygiene resources for } \\
\text { sustainable development }\end{array}$} & \multirow{4}{*}{$\begin{array}{l}\text { Mainstreamed } \\
\text { target }\end{array}$} & Regulate harvesting and end over fishing, illegal, unreported and unregulated \\
\hline & & fishing and destructive fishing practices. Prohibit certain forms of fisheries \\
\hline & & subsidies which contributes to overcapacity and overfishing. Provide access \\
\hline & & for small-scale artisanal fishers to marine resources and markets. \\
\hline & \multirow{2}{*}{$\begin{array}{l}\text { Target not } \\
\text { mainstreamed }\end{array}$} & Prevent and reduce marine pollution of all lands. Sustainably manage and \\
\hline & & $\begin{array}{l}\text { protect marine and coastal ecosystem. Minimize and address the impact of } \\
\text { ocean acidification. }\end{array}$ \\
\hline
\end{tabular}

Goal 15: Protect, Mainstreamed Combat desertification, restore land and soil

sustainable use of forest, target

halt land degradation Targets not Ensure the conservation and sustainable use of fresh water ecosystem and and biodiversity loss mainstreamed their services. Promote the implementation of sustainable management of all types of forest. Conservation of mountain ecosystem. Reduce degradation of natural habitat etc

Goal 16: Promote Peace Mainstreamed Promote and enforce non-discriminatory laws and policies for sustainable and institutions in all target development. Reduce all forms of violence. End abuse, exploitation, level trafficking etc. Promote rule of law. Reduce corruption and bribery. Develop accountable and transparent institutions. Provide legal identity for all, including birth registration. Ensure public access to information and protect freedom.

\begin{tabular}{|c|c|c|}
\hline & $\begin{array}{l}\text { Targets not } \\
\text { mainstreamed }\end{array}$ & $\begin{array}{l}\text { Strengthen the recovery and return of stolen assets. Broaden and strengthen } \\
\text { the participation of developed countries in the institutions of global } \\
\text { governance. }\end{array}$ \\
\hline \multirow[t]{2}{*}{$\begin{array}{l}\text { Goal 17: Partnerships for } \\
\text { the goals }\end{array}$} & $\begin{array}{l}\text { Mainstreamed } \\
\text { target }\end{array}$ & $\begin{array}{l}\text { Strengthen domestic resource mobilization. Assist developing countries in } \\
\text { attaining long-term debt sustainability. Enhance policy coherence for } \\
\text { sustainable development. Enhance global partnership for sustainable } \\
\text { development. Encourage and promote effective public, public-private and } \\
\text { civil society partnerships. }\end{array}$ \\
\hline & $\begin{array}{l}\text { Targets not } \\
\text { mainstreamed }\end{array}$ & Promote universal, rule-based, nondiscriminatory trading system etc \\
\hline
\end{tabular}

\subsection{Mainstreaming Processes at the Local Level}

The mainstreaming processes at the local level included stakeholder engagement, planning, budgeting, implementation, monitoring and evaluation.

\subsubsection{Stakeholder Engagement}

Stakeholders are essential in the formulation of the local development plan of municipals. 
The assembly engage stakeholders in planning which confirmed what the respondents said:

We engage our stakeholders and we organize workshops at the various electoral area. The residents in this place and other stakeholders were consulted, that is what we always do in preparing our medium-term development plan"

More so, from Partnership for Action and Green Economy (PAGE) 2017, the key stakeholders for mainstreaming the SDGs at the local level including youth, women, parliamentarians, local decision makers, traditional authorities, religious groups, civil society organization and farmers were confirmed from respondents' responses and Medium Term Development Plan of the assembly.

The views and opinions of the stakeholders were solicited in preparing the local plan which were treated with much respect

"Stakeholders were involved in every situation in terms of presenting issues and bringing in their problems, they were also given the opportunity to air their views out during those meetings which aided in preparing the local development plan of the municipal".

Afterward, the leaders of the assembly performed a needs assessment, prioritized based on available resources and went back to the stakeholders to explain their difficulties to them. This proposal was accepted as the Local Development Plan only after it was accepted by the stakeholders

"after collecting input we prioritize the needs which form bases for the planning process, then we arrange them based on NDPC planning project, it goes for approval by the assembly members, once they approve, its good for implementation"

It is important to add that though stakeholders were involved in preparing the local development plan, it was the leadership of the Municipal Assembly who mapped the local development plan with the SDGs and its targets.

\subsubsection{Planning Processes}

The planning process is very critical in mainstreaming the goals into local development plan. The National Development Planning Commission (NDPC) led the planning process by giving the Assembly a guideline on how the SDGs should be mainstreamed

"we get the guidelines from the NDPC and when we are doing our plans we incorporate them into the plan"

In planning the municipal did assessment and prioritization of activities based on resources available

"We do needs assessments, prioritize based on available resources, then we develop projects around to address the issue but because of limited resources we put them in timelines".

Moreover, the medium term development plan of the Assembly revealed that they used their regular planning techniques in mainstreaming the SDGs which includes preparation of district profiles, district development priorities, goals, strategies and objectives, development of Program of Action and Annual Action Plan.

\subsubsection{Budgeting}

Proper budgeting determines the success of the SDG mainstreaming. Under budgeting the respondent only mentioned that the mainstreamed goals were captured in the budget

"we capture it in our budget and once the funds are available we put them into implementation"

"the mainstreamed goals are actually what it is in the budget".

However, the findings did not reveal that the Municipal Assembly agreed on expected outputs that would lead to the achievement of the SDGs nor compared cost to available resources in order to reprioritize it to fit within the available resources which are essential in budgeting in achieving these goals.

\subsubsection{Monitoring, Evaluation and Reporting}

Strong monitoring and evaluation and reporting systems are essential in achieving the goals at the local level. The respondents demonstrated that there are effective monitoring assessments to track progress of the mainstream goals

We have a monitoring team made up of planning unit, the works department and the Internal audit and when a department is implementing a particular thing, they go out and try to find out exactly what is going on vis a vis how it has been budgeted ..."

The municipal used their regular monitoring and evaluation plan in tracking progress of the goals

well the truth is that the assembly don't necessarily have SDGs specific monitoring but we do have a monitoring framework of the assembly in monitoring the local development plan" 
More so, the Municipal Assembly added the SDG indicators to their usual indicators in tracking progress of the goals

"the indicators of the mainstreamed goals are added to the assembly's monitoring indicators to form part of our usual monitoring"

"the monitoring framework also takes inspirations from the indicators from the SDGs and the national framework"

In terms of reporting of the mainstreamed goals, the respondent had diverse and similar views on that

"We report to our supervisory agencies eg the Regional Coordinating Council and the Ministry of Local Government and we will continue to report to them as such"

Reporting of the goals are also done internally and externally

"the reporting is done from two angles, first we have internal reporting and we also have external reporting, we have quarterly progress reporting which we circulate with NDPC and the Regional Coordinating Council (RCC) and then we have the Annual progress report which is a consolidation of the various quarterly progress report".

4.2.5 Means of Implementation

The successful implementation of the goals depends on the availability of the financial resources of the Assembly. The SDGs acknowledge multi-stakeholder partnerships as essential means for mobilizing and sharing knowledge and financial resources to support the goals and even though the Municipal Assembly involved the stakeholders, they were not informed to assist financially.

Most of the respondents emphasized that implementation of the goals were based on the relevance of the goals to the community or the assembly:

"We look at the various thematic areas, we look at the ones we can implement that is the relevant ones,...then we mainstream".

For effectiveness, implementation of the mainstreamed goals are in segregation, thus the goals are implemented at departmental level. For instance a goal which is health-related will be implemented by the health directorate of the Municipal Assembly.

"we implement them through our usual activities..., if the plan of action is on child abuse we have the social welfare department available to implement, so the implementation is segregated into department"

The respondents also revealed that because of limited resources, all the 17 SDGs goals cannot be implemented, therefore since the MTDP is for a period of (4) years, the Assembly budget for what can be implemented within that period.

We do needs assessment, prioritize activities based on available resources then we put them in various timelines then we develop projects around to address the issues but because of limited resources, we put them in timelines)'.

"we can't implement all the goals at the same time so depending on the guidelines that are given to us, if we are considering five (5) goals at a given period we make sure we have a budget line for them"

Respondents from the municipal mentioned the main sources of fund for implementing the local development plan.

"With the mobilization of funds in implementing the SDGs, we have the Internally Generated Funds, we have those funds from the Central Government and we have Donor fund."

\subsection{Effectiveness of the Mainstreamed Goals}

The SDG indicators measures the criteria used in determining the effectiveness of the mainstreamed goals. The findings indicate that the Municipal Assembly have indicators for tracking progress on their local development plan and also added the SDG indicators to their existing indicators in tracking progress of the goals. The indicators have indicator type which looks at whether a particular indicator is an output or an outcome, it also has monitoring frequency and responsibilities. The monitoring frequency determine the number of times either quarterly or annually an indicator would be tracked, and the responsibilities are the units or agencies responsible for the monitoring. Using the indicators, it appears that the municipal has effectively mainstreamed the goals. However, to ensure that the goals have effectively been mainstreamed, it is laudable to also do a historical analysis on the budget of the Municipal Assembly to know whether they have been able to acquire funds in implementing local development plan. This is because resource is essential to successful implementation of the goals. 
Table 2. Budgeting at the municipal level expenditure (Adentan-municipal)

\begin{tabular}{|c|c|c|c|c|c|c|}
\hline & 2014 & & & 2015 & & \\
\hline & PLANNED & ACTUAL & VARIANCE & PLANNED & ACTUAL & VARIANCE \\
\hline GOG & $10,000.00$ & $105,454.03$ & $95,454.03$ & $30,000.00$ & $129,520.00$ & $99,520.00$ \\
\hline IGF & $3,349,204.48$ & $3,236,141.48$ & $113,062.79$ & $4,773,707.96$ & $4,661,318.42$ & $112,389.54$ \\
\hline DACF & $1,186,104.75$ & $566,798.07$ & $619,306.68$ & $2,210,000.00$ & $2,101,482.22$ & $108,517.78$ \\
\hline UDG & & $312,000.00$ & $(312,000.00)$ & $955,544.82$ & $9,555,444.82$ & $(8,599,900.00)$ \\
\hline PWD & $23,722.09$ & $17,171.18$ & $6,550.91$ & $53,221.41$ & $40,422.76$ & $12,798.65$ \\
\hline GAMA & $400,000.00$ & $393,395.41$ & $6,604.59$ & $600,000.00$ & $210,725.94$ & $389,274.06$ \\
\hline MSHAP & & & & $750,000.00$ & $487,254.50$ & $262,745.50$ \\
\hline MPS CF & $5,930.52$ & & $5,930.52$ & $13,305.35$ & $9,161.62$ & $4,143.73$ \\
\hline SIF & $150,000.00$ & $42,856.67$ & $107,143.33$ & $280,000.00$ & $175,041.72$ & $104,958.28$ \\
\hline \multicolumn{7}{|c|}{ SCH FEEDING } \\
\hline EU PROJES & $452,592.00$ & $468,045.80$ & $(15,453.80)$ & $350,000.00$ & $270,533.00$ & $79,467.00$ \\
\hline \multirow[t]{4}{*}{ CEN GOV' } & $1,400,000.00$ & $1,004,904.95$ & $395,095.05$ & $1,110,000.00$ & $983,698.95$ & $126,301.05$ \\
\hline & $6,977,553.84$ & $6,146,767.59$ & $1,021,694.10$ & $11,125,779.54$ & $18,624,603.95$ & $(7,299,784.41)$ \\
\hline & 2016 & & & 2017 & & \\
\hline & PLANNED & ACTUAL & VARIANCE & PLANNED & ACTUAL & VARIANCE \\
\hline GOG & $42,097.00$ & $31,326.00$ & $10,771.00$ & $131,277.00$ & $10,000.00$ & $121,277.00$ \\
\hline IGF & $6,042,083.00$ & $5,405,618.07$ & $636,464.93$ & $7,478,880.00$ & $1,451,548.83$ & $6,027,331.17$ \\
\hline DACF & $2,838,300.00$ & $2,154,536.83$ & $683,763.17$ & $3,712,225.00$ & 540.00 & $3,711,685.00$ \\
\hline UDG & $1,719,400.00$ & $793,040.00$ & $926,360.00$ & $1,075,000.00$ & & $1,075,000.00$ \\
\hline PWD & $100,000.00$ & $105,746.06$ & $(5,746.06)$ & $150,000.00$ & & $150,000.00$ \\
\hline GAMA & $398,221.79$ & $368,982.00$ & $29,239.79$ & $486,795.00$ & & $486,795.00$ \\
\hline MSHAP & $2,578,000.00$ & $1,904,220.87$ & $673,779.13$ & $5,309,400.00$ & $1,000,360.00$ & $4,309,040.00$ \\
\hline MPS CF & $16,000.00$ & $13,096.24$ & $2,903.76$ & $10,290.00$ & & $10,290.00$ \\
\hline SIF & $180,000.00$ & $46,732.03$ & $133,267.97$ & $200,000.00$ & & $200,000.00$ \\
\hline SCH FEEDI & $100,000.00$ & & $100,000.00$ & $100,000.00$ & 500.00 & $99,500.00$ \\
\hline \multicolumn{2}{|c|}{ EU PROJECT } & $1,522,665.44$ & $(1,522,665.44)$ & & $11,625.91$ & $(11,625.91)$ \\
\hline \multirow[t]{2}{*}{ CEN GOV' } & $1,978,018.00$ & $1,137,050.28$ & $840,967.72$ & & & \\
\hline & $15,992,119.79$ & $13,483,013.82$ & $2,498,334.97$ & $18,653,867.00$ & $2,474,574.74$ & $16,179,292.26$ \\
\hline
\end{tabular}

In Adentan, Government of Ghana (GoG) actuals were higher than planned except 2016, 2017.

With District Assembly Common Fund (DACF), Adentan Municipal Assembly sometimes receive half of planned amount and other times received almost the amount planned for the year. In 2014, the Assembly planned $1,186,104.75$ but received almost half of the planned amount, 566,798.07 and in 2017, the planned 3,712,225.00 exceeded the actual of 540.00 received. But then, in 2015, the actual received of 2,101,482.22 were closer to the amount planned of 2,210,000.00 which was also evident in 2016.

With Urban Development Grant (UDG), it is very difficult to make predictions of the future in Adentan, because in 2015, the Municipal Assembly planned 955,544.82 for UDG and interestingly, the actual received was an amount of 9,555,444.82, a magnificent increase from the planned budget. However, in 2016, the Municipal Assembly planned $1,719,400.00$ but had a decline of 793,040.00 on the actuals received, this means when the budgeted amount by the Assembly was high, it received lower actuals and vice versa making it difficult to make future predictions on UDG in Adentan municipal. From a detailed perspective, it is evident that Adentan Municipal Assembly has more financial sources than the three main financial sources mentioned by the respondents.

An increased population would necessitate an increase in finances to eradicate poverty, reduce hunger, enhance health systems, ensure quality education, decent jobs among others. For the Municipal Assembly to achieve its targeted mainstreamed goals, more efforts is needed to increase financing at the local level. Municipal Chief Executive can lead the change in exploring opportunities in the municipality to increase the internally generated funds, encourage public private partnerships, internally and externally searching for avenues to support programs and projects of the Assembly among others. 
It is evident that Adentan municipal has effectively mainstreamed the SDGs which is to say that Adentan Municipal Assembly can effectively implement their local development plan.

\subsection{Mainstreaming Challenges at the Local Level}

From the literature, financing of the goals was the main challenge of the SDG mainstreaming. The findings show an evidence of funding being a major challenge. Aside funding, limited awareness of the relevance of the SDGs, bureaucracy, unreliable data and information from stakeholders, lack of commitment and competent human resource, difficulty in allocating an activity to an SDG were mentioned by the assembly as challenges in mainstreaming the SDGs.

Table 3. SDG mainstreaming challenges at the local level

\begin{tabular}{ll}
\hline \multicolumn{2}{l}{ Challenges faced by Adentan municipal in mainstreaming SDGs } \\
\hline - & Unreliable data and information from Stakeholders \\
- & Limited awareness of the relevance of the SDG \\
- & Lack of commitment and competent human resource \\
- & Bureaucracy \\
- & Inadequate funding \\
- & Difficulty in allocating an activity to an SDG \\
\hline
\end{tabular}

\section{Conclusion}

Generally the SDGs have been mainstreamed into the local development plan of Adentan Municipal Assembly. The number of targets mainstreamed are appreciable and even beyond the expectations of the Ghana Baseline Report, 2018. SDG 1, 2, 3,4,5,6,8,9,10,11, 13,14,16 and 17 have positively been mainstreamed into the local development plan of the municipal. However, the municipal shown low interest in SDG 7 and 15. The major challenges on the mainstreaming of the goals were resources especially finances, low awareness of the relevance of the SDGs and bureaucracy which, if attention is not given would affect massively the implementation of the goals leading to the impossibility of achieving the goals by 2030 . The study provided feedback on policies on SDG mainstreaming precisely at the local level, which was critical in ensuring the accomplishment of goals by 2030 . These contributions to policy and practice would become relevant to the development of more effective SDG mainstreaming at the local level.

The study adds to literature on SDG mainstreaming at the local level. The findings from the study revealed a lot of factors that influence SDG mainstreaming at the local level such as government support, intervention and supervision, high commitment, constant exploration of avenues for resources, efficient and effective resource management, awareness building, political leadership, institutional structures, robust coordination, technical support, financing, budgeting, stakeholder engagement, planning, implementation, monitoring and evaluation among others.

\subsection{Framework for Effective Mainstreaming of SGDs in Local Development Plans}

The framework provided below represents the major contribution of the study to literature. It combines literature reviewed and recommendation provided in the study. This framework is believed to be a comprehensive framework for an effective SDG mainstreaming at the local level which could also be added to other existing framework on SDG mainstreaming at the local level. 


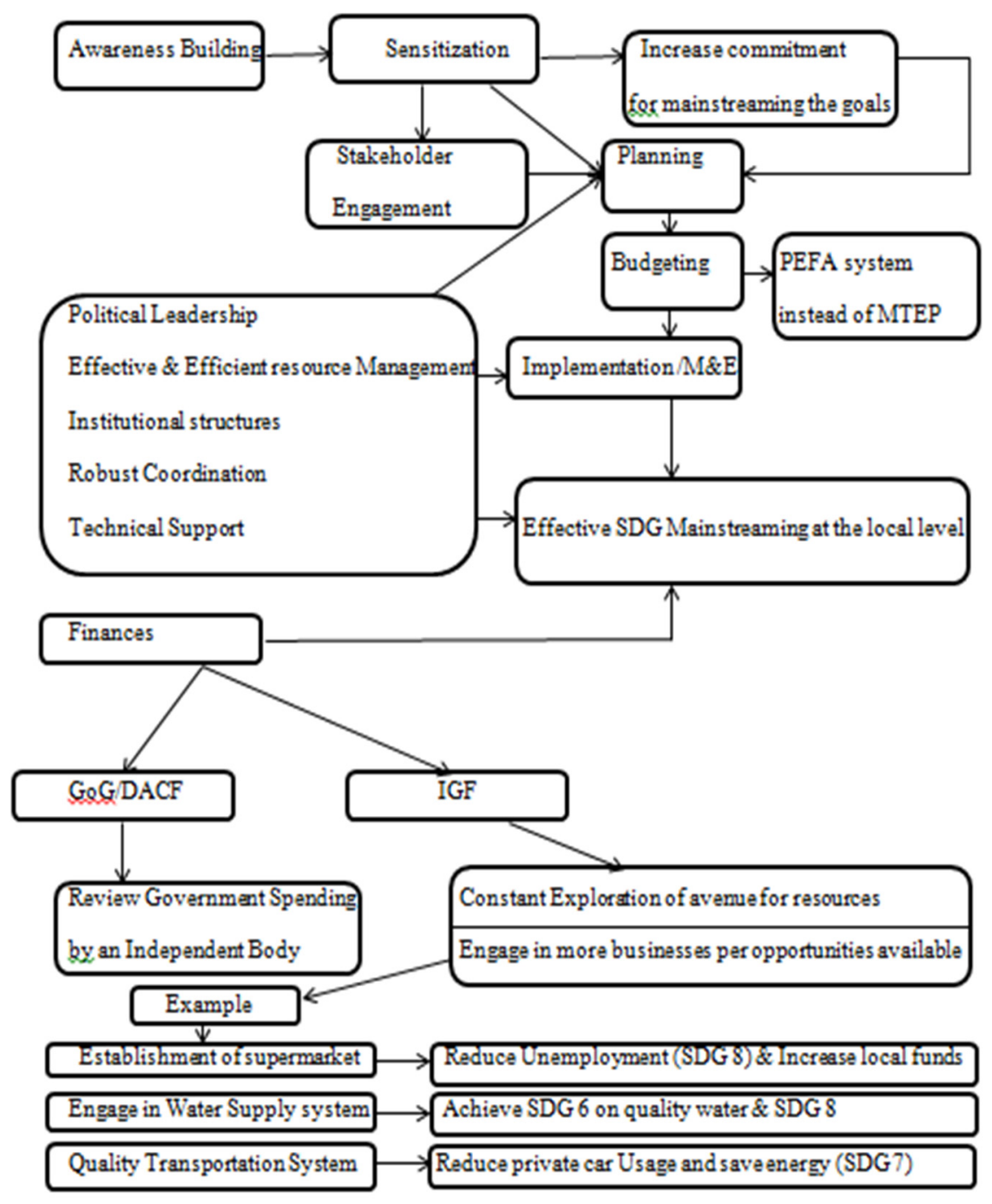

Figure 2. Framework for an effective SDG mainstreaming at the local level

\subsection{Recommendations}

There is the need for sensitization to popularize the relevance of the SDGs to all citizens especially the stakeholders who would be involved in the SDG planning. The sensitization would invariably increase commitment for mainstreaming the goals by not only stakeholders but employers and employees at the various department of the Municipal Assembly. The awareness of the relevance of the goals would automatically affect planning positively at the initial stage of the preparation of the local development plan which would impact budgeting and influence implementation of the goals. High commitment from political leaders is also very necessary in achieving the goals. This is because in Ghana for instance, the local authority is not fully autonomous and takes inspirations from decisions of the central government on how operations at the local level ought to be. Effective and efficient resource management, institutional structures, robust coordination and technical support affect all aspects of the SDG mainstreaming process. For instance, coordination is needed to bring all the institutional structures involved including the various departments with their technical support, effective and efficient resource management is required to ensure that the limited resources available have been used to achieve the highest level of significance than it would otherwise have been used. On budgeting, the Municipal Assembly use the Medium-Term Expenditure Plan (MTEP) but it appears that the Public Expenditure and Financial Accountability (PEFA) is broader and essential in managing public finances than the MTEP used in the Municipal Assembly. The PEFA Framework uses seven (7) key pillars and 31 sub-indicators to account for Public Financial Management outturns in countries. The seven pillars includes: policy-based fiscal strategy and budgeting which ensures that the budget 
is prepared with regard to government policy.

Predictability and control in budget also ensure that the implementation of the budget is done in an orderly and inevitable manner with stewardship existing in the usage of public funds. Budget credibility looks at whether the budget is realistic and can be carried out. Accounting and reporting ensures that enough records and information are developed including reporting systems as well. External scrutiny and audits ensure that external arrangement operates for the examination of public finances and follow ups are done by the executive. Transparency of public finances looks at how budget information becomes accessible to the public and whether the budget and it risks involved are comprehensive. Donor support ensures that resources granted are guided by rules of the donor. These are essential for effective budgeting.

Financing is an important mechanism towards achieving the SDGs. This requires the need to increase resources towards achieving the goals. In Ghana, the major sources of funding at the local level are the District Assembly Common Fund, Internally Generated Fund and Donor support. The ability to get the donor support is not certain and is based on a lot of factors from the preferences of the donors. To increase DACF and funds from Government of Ghana (GoG), there should be a critical review of Government spending by an independent entity whose appointment is based strictly on meritocracy than by a political leader. The independent body would ensure transparency and accountability of all spending in government. Moreover, the review would reveal persons whose salaries and allowances are overly paid and other unaccounted spending. This can possibly increase funds given to the Municipal Assembly at the local level in achieving local development plan.

On Internally Generated Fund (IGF), the Municipal Assembly must constantly explore avenues for resources and explore avenues for funds from international bodies. There should be partnership between the Municipal Assembly and other business entities to increase funds internally. More so, the Municipal Assembly can engage in more businesses per opportunities available.

The municipality have serious water problems. Here the Municipal Assembly can establish a water supply system amidst the limited resources available, residents would pay less and get access to quality water than buying from private vendors which are very expensive and of low quality. Profit from this would increase funds of the Assembly, create employment (SDG 8), and aid in achieving SDG 6 on access to quality water and many more.

\section{References}

Alhassan, S., \& Hadwen, W. L. (2017). Challenges and opportunities for mainstreaming climate change adaptation into WaSH development planning in Ghana. International journal of environmental research and public health, 14(7), 749. https://doi.org/10.3390/ijerph14070749

Atango et. Al. (2017). The Challenges of Climate Proofing Local Plans for Sustainable Development in Ghana. KNUST Journal of Geography and Development, 2.

Ayers, J., Huq, S., Wright, H., Faisal, A. M., \& Hussain, S. T. (2014). Mainstreaming climate change adaptation into development in Bangladesh. Climate and Development, 6(4), 293-305. https://doi.org/10.1080/17565529.2014.977761

Donaires, O. S., Cezarino, L. O., Caldana, A. C. F., \& Liboni, L. (2019). Sustainable development goals - an analysis of outcomes. Kybernetes, 48(1), 183-207. https://doi.org/10.1108/K-10-2017-0401

Lebel, L., Li, L., Krittasudthacheewa, C., Juntopas, M., Vijitpan, T., Uchiyama, T., \& Krawanchid, D. (2012). Mainstreaming climate change adaptation into development planning. Bangkok: Adaptation Knowledge Platform and Stockholm Environment Institute, 8.

Lucci, P., \& Lally, S. (2016). Starting Strong: The first 1000 days of the SDGs. Informing a set of regional dialogues on SDG early implementation. Overseas Development Institute. London.

Muff, K., Kapalka, A., \& Dyllick, T. (2017). The Gap Frame-Translating the SDGs into relevant national grand challenges for strategic business opportunities. The International Journal of Management Education, 15(2), 363-383. https://doi.org/10.1016/j.ijme.2017.03.004

Ntona, M., \& Morgera, E. (2018). Connecting SDG 14 with the other Sustainable Development Goals through marine spatial planning. Marine Policy, 93(June 2017), 214-222. https://doi.org/10.1016/j.marpol.2017.06.020

Oates, N., Conway, D., \& Calow, R. (2011). The'mainstreaming'approach to climate change adaptation: insights from Ethiopia's water sector.

Okafor-Yarwood, I. (2019). Illegal, unreported and unregulated fishing, and the complexities of the sustainable 
development goals (SDGs) for countries in the Gulf of Guinea. Marine Policy, 99(October 2017), 414-422. https://doi.org/10.1016/j.marpol.2017.09.016

Pisano, U., Lepuschitz, L. K., \& Berger, G. (2015). The European Context for monitoring and revewing SDGs: How EU Member States and the European level are approaching the Post- 2015 Agenda.

Ribeiro, P., Ferrão, J., \& Seixas, J. (2018). Mainstreaming climate adaptation in spatial planning. The case of Baixa Pombalina in Lisbon. Finisterra, 53(108), 15-38. https://doi.org/10.18055/Finis13457

Uittenbroek, C. J., Janssen-Jansen, L. B., \& Runhaar, H. A. (2013). Mainstreaming climate adaptation into urban planning: overcoming barriers, seizing opportunities and evaluating the results in two Dutch case studies. Regional environmental change, 13(2), 399-411. https://doi.org/10.1007/s10113-012-0348-8

UNDP. (2007). Localizing the MDGs for Effective Integrated Local Development: An Overveiw of Practices and Lessons learned. Retrieved from http:web.Ialnclrebon.ac.id/ebook/moom/Reginal studies

United Nations. (2015). Sustainable Development Solutions Network, 2015. Indicators and a Monitoring Framework for the Sustainable Development Goals: Launching a data revolution for the SDGs. Retrieved from http://unsdsn.org/wp-content/uploads/2015/05/FINAL-SDSN-Indicator-Report-WEB.pdf

Weymouth, R., \& Hartz-Karp, J. (2018). Principles for integrating the implementation of the sustainable development goals in cities. Urban Science, 2(3), 77. https://doi.org/10.3390/urbansci2030077

\section{Copyrights}

Copyright for this article is retained by the author(s), with first publication rights granted to the journal.

This is an open-access article distributed under the terms and conditions of the Creative Commons Attribution license (http://creativecommons.org/licenses/by/4.0/). 